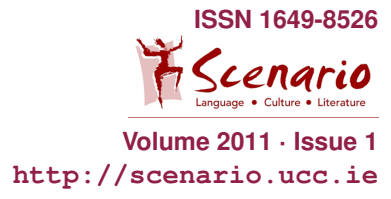

TaT - Texts around Theatre - TaT

\title{
MOMO
}

\section{Michael Ende}

\begin{abstract}
Momo's story is that of a small girl who confronts the time-thieves; grey gentlemen who rob humankind of their time and therefore of their quality of life. The fact that the human beings are unconsciously making their loss of time possible should serve as a lesson to us all. - Momo is singularly equipped for the battle: she possesses incredible listening skills, so that "suddenly clever things occurred even to stupid people. [...] She could listen so that people at a loss all of a sudden knew exactly what they wanted. Or that shy people suddenly felt free and courageous..." (translation Susanne Even). And other childrens' games take off in unforeseen directions when she is around; they become happenings, dramatic experiences. The little stray Momo lives in an old, derelict amphitheatre, and this is where this story begins...
\end{abstract}

\section{The Amphitheatre}

Long, long ago, when people spoke languages quite different from our own, many fine, big cities existed in the sunny lands of the world. There were towering palaces inhabited by kings and emperors; there were broad streets, narrow alleyways and winding lanes; there were sumptuous temples filled with idols of gold and marble; there were busy markets selling wares from all over the world; and there were handsome, spacious squares where people gathered to discuss the latest news and make speeches or listen to them. Last but not least, there were theatres - or, more properly, amphitheatres.

An amphitheatre resembled a modern circus, except that it was built entirely of stone. Seats for spectators were arranged in tiers, one above the other, like steps lining the crater of a man-made volcano. Many such buildings were circular, others semi-circular, others oval.

Some amphitheatres were as big as football stadiums, others could hold no more than a few hundred people. Some were resplendent with columns and statues, others plain and unadorned. Having no roofs, amphitheatres were open to the sky. This was why, in the more luxurious ones, spectators were shielded from the heat of the sun or from sudden downpours by gold-embroidered awnings suspended above their seats. In simple amphitheatres, mats woven of rushes or straws served the same purpose. In 
short, people made their amphitheatres as simple or luxurious as they could afford. But they all wanted to have one, since they were passionate listeners and observers.

And whenever they saw exciting or amusing incidents acted out on stage, they felt as if this make-believe happenings were more real, in some mysterious way, than their own humdrum lives. And they loved to harken to this other kind of reality.

Thousands of years have passed since then. The great cities of long ago lie in ruins, together with their temples and palaces. Wind and rain, heat and cold have worn away and eaten into the stonework. Ruins are all that remain of the amphitheatres too. Crickets now inhabit their crumbling walls, singing a monotonous song that sounds like the earth breathing in its sleep.

A few of these cities have survived to the present day, however. Life has changed, of course. People ride around in cars and buses, have telephones and electric lights. But here and there among the modern buildings one can still find a column or two, and archway, a stretch of wall, or even an amphitheatre dating from olden times.

It was in a city of this kind that the story of Momo took place.

From First Chapter of: Michael Ende: Momo. London, Puffin Books

(C) Copyright \& Permissions Department, Penguin Group UK, 80 Strand, London, WC2R ORL 